\title{
자주색집뇨관중후군
}

\author{
한지은 오진영 김태민 한상원
}

인제대학교상계백병원 신경과

\section{Purple Urine Bag Syndrome}

\author{
Ji Eun Han, MD, Jinyoung Oh, MD, Taemin Kim, MD, Sang Won Han, MD \\ Department of Neurology, Inje University Sanggye Paik Hospital, Seoul, Korea
}

J Korean Neurol Assoc 39(2):99, 2021

87세 여자가 우측 중대뇌동맥영역 뇌경색으로 입원하여 도뇨관 을 유치하던 중 14 일째부터 집뇨 주머니가 자주색으로 착색되었다 (Fig.). 생체징후는 혈압 $143 / 76 \mathrm{mmHg}$, 맥박수 76 회/분, 호흡수 14 회/분, 체온 $36.5^{\circ} \mathrm{C}$ 였다. 소변검사에서 $\mathrm{pH} 7.0$, 단백뇨 및 세균 뇨가 관찰되었으며 세균배양에서 폐렴막대균(Klebsiella pneumoniae)이 동정되었다. 증상은 시프로플록사신 정맥 투여 및 도뇨관 교체로 호전되었다.

자주색집뇨관증후군(purple urine bag syndrome)은 집뇨 주머 니나 집뇨관이 자주색 또는 파란색으로 착색되는 현상으로 장기 입원 환자들에게서 매우 드물게 관찰된다. ${ }^{1}$ 발생 기전으로는 Proteus mirabilis, 대장균(Escherichia coli), 녹농균(Pseudomonas aeruginosa), Morganella morganii, Klebsiella pneumoniae 및 장 알균<속> (Enterococcus sp.) 같은 박테리아 요도 감염과 관련이 있다. 경구 섭취한 트립토판(tryptophan)은 장내 세균에 의해 인돌 (indole)로 대사되어 문맥 순환계로 흡수된 후 인독실황산염 (indoxyl sulphate)으로 분해되어 소변으로 배출되는데 이들 박테 리아는 인독실황산염을 인디루빈(indirubin, 적색)과 인디고(indigo, 청색)로 변화시키는 인독실 인산염분해효소 및 황산염분해효소 (indoxyl phosphatase /sulfatase)를 생성한다. ${ }^{1,2}$ 이렇게 발생한 두 물질이 혼합되어 보라색 소변을 형성하는데 주로 트립토판 과다

Received January 5, 2021 Revised January 29, 2021

Accepted January 29, 2021

Address for correspondence: Sang Won Han, MD

Department of Neurology, Inje University Sanggye Paik Hospital, 1342 Dongil-ro, Nowon-gu, Seoul 01757, Korea

Tel: +82-2-950-1090 Fax: +82-2-950-1955

E-mail:swhan@paik.ac.kr

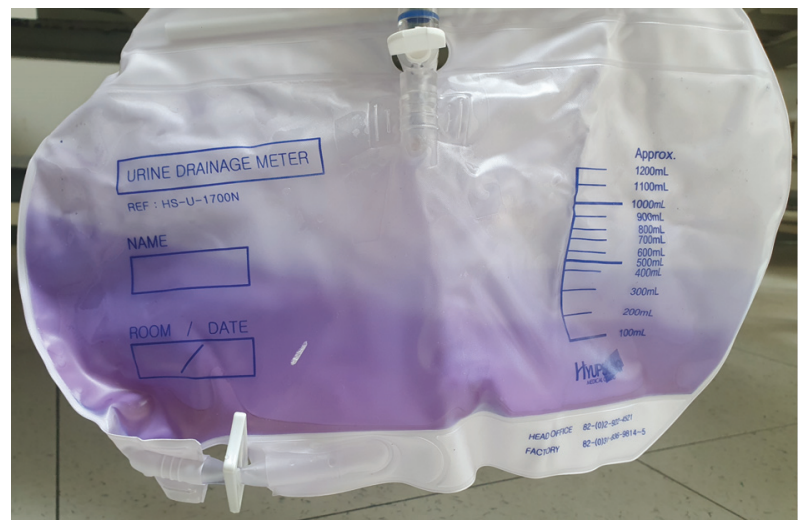

Figure. Urine bag displaying the typical purple discoloration in purple urine bag syndrome.

섭취, 신부전, 변비 및 알칼리성 소변을 보이는 고령의 여성에서 장기간 도뇨관을 유치하는 경우 발생한다. ${ }^{2}$ 치료는 증상에 대한 자 세한 설명과 함께 방광세척 및 도뇨관 교체가 우선이나 필요시 동 정된 균주에 따른 항생제 투여가 필요하다. ${ }^{1,2}$

\section{REFERENCES}

1. Ga H. Purple urine bag syndrome. J Korean Geriatr Soc 2008;12:1-4.

2. de Menezes Neves PDM, Coelho Ferreira BM, Mohrbacher S, Renato Chocair P, Cuvello-Neto AL. Purple urine bag syndrome: a colourful complication of urinary tract infection. Lancet Infect Dis 2020;20: 1215. 